\title{
Airborne radar survey above Vostok region, east-central Antarctica: ice thickness and Lake Vostok geometry
}

\author{
Ignazio E. TABACGO, ${ }^{1}$ Cesido BIANCHI, ${ }^{2}$ Achille ZIRIZZOTTI, ${ }^{2}$ Enrigo ZUCGHERETti, ${ }^{2}$ \\ Alessandro FORIERI, ${ }^{1}$ Alessio Della VeDOVA ${ }^{1}$ \\ ${ }^{1}$ Department of Earth Science, University of Milan, Via Cicognara 7, I-20129 Milan, Italy \\ E-mail:ignazio.tabacco@unimi.it \\ ${ }^{2}$ National Institute of Geophysics and Vulcanology ( INGV), Via di Vigna Murata, I-00143 Rome, Italy
}

\begin{abstract}
During the 1999-2000 Italian Expedition, an airborne radar survey was performed along 12 transects across Lake Vostok, Antarctica, and its western and eastern margins. Ice thickness, subglacial elevation and the precise location of lake boundaries were determined. Radar data confirm the geometry derived from previous surveys, but with some slight differences. We measured a length of up to $260 \mathrm{~km}$, a maximum width of $81 \mathrm{~km}$ and an area of roughly $14000 \mathrm{~km}^{2}$. Along the major axis, from north to south, the ice thickness varies from 3800 to $4250 \mathrm{~m}$, with a decreasing gradient. From west to east the ice thickness is fairly constant, except for two narrow strips located on the western and eastern margins, where it increases with high thickening rate. Over the lake the surface elevation increases from $3476 \mathrm{~m}$ a.s.l. (south) to 3525 (north), with a decreasing gradient, while the lake surface elevation decreases from -315 to $-750 \mathrm{~m}$ a.s.l., with a decreasing gradient (absolute value). The icesurface and lake-ceiling slopes suggest that the lake is in a state of hydrostatic equilibrium.
\end{abstract}

\section{INTRODUCTION}

The discovery of Lake Vostok, east-central Antarctica, involved many scientists over a period of more than four decades. Oswald and Robin (1973) were the first to bring to light the existence of a subglacial lake beneath the Vostok region, based upon a radio-echo sounding survey. The rough dimensions of the subglacial lake were obtained by Ridley and others (1993) from analysis of the ice-sheet surface topography. A seismic survey performed in 1964 by Russian scientists was re-analyzed, allowing the water thickness to be calculated (Kapitsa and others, 1996). The existence of a water body was confirmed by isotope studies indicating that the Vostok ice core, from $3539 \mathrm{~m}$ below the ice surface to its bottom, consists of refrozen ice from Lake Vostok water (Jouzel and others, 1999).

\section{MEASUREMENTS}

During the 1999-2000 Italian Expedition, airborne icepenetrating radar measurements were made over the VostokDome $\mathrm{C}$ region in order to increase our knowledge of Lake Vostok and its boundary, and to contribute towards the reconnaissance of the entire area's bed morphology. The choice of flight-lines was based on analysis of the ice-sheet surface topography (Siegert and Ridley, 1998; Rémy and others, 1999; Siegert and others, 2000) and on the Kapitsa outline of the lake (Kapitsa and others, 1996). This paper confines itself to setting forth results from the flights made over the Vostok region. The radar lines are located in Figure 1. The transects "ew2" and "ew3" over the lake run parallel to the flowlines (Kwok and others, 2000), while the transects "ewl" and "ew4" present an angle of approximately $20^{\circ}$ and $8^{\circ}$,

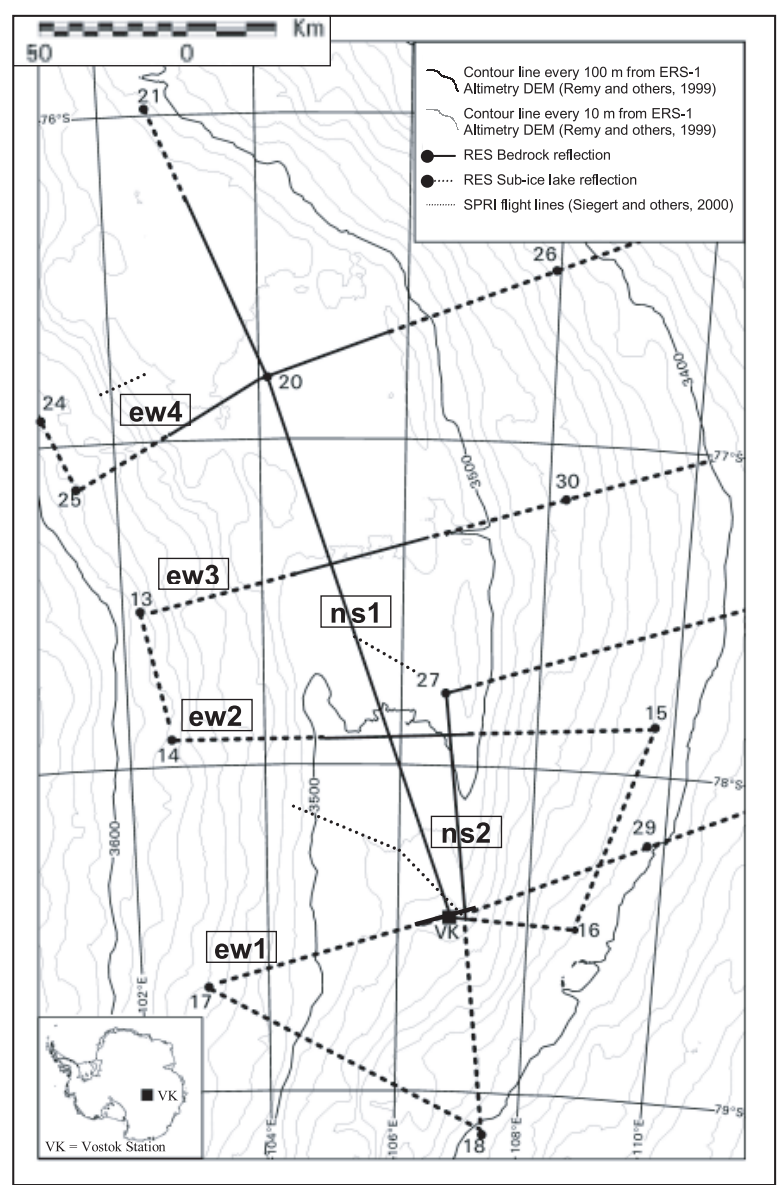

Fig. 1 Location of radio-echo sounding flight-lines of Italian Expedition 1999 and of Scott Polar Research Institute (SPRI)-Technical University of Denmark (TUD)-U.S. National Science Foundation (NSF) survey (Siegert, 2000). VK, Vostok station. 


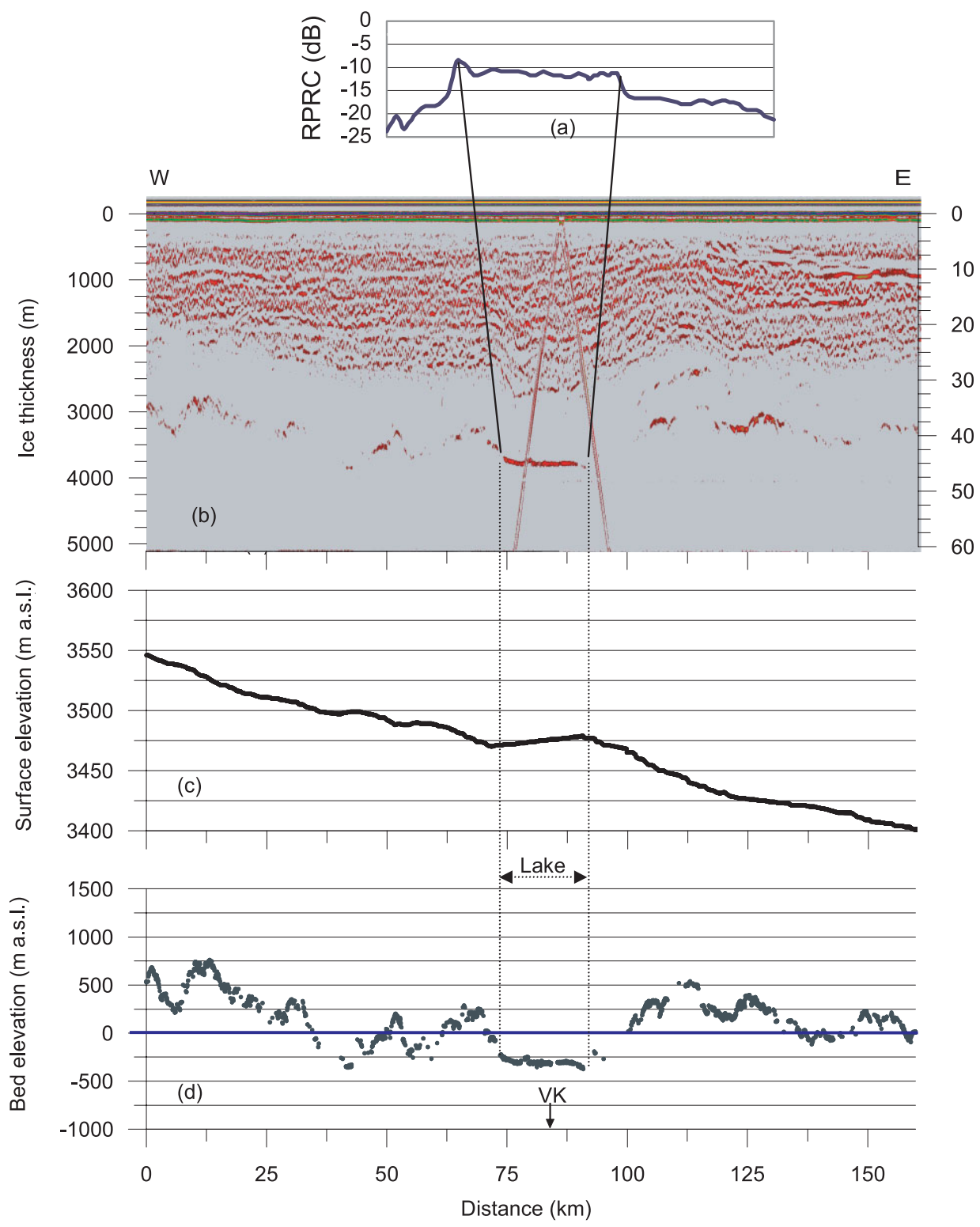

Fig. 2. Transect "eww". (a) RPRC; (b) radar sections with ice thickness and two-way time (TWT); (c, d) surface and bed elevation, respectively ( $m$ a.s.l.).

respectively. The transects "nsl" and "ns2" are roughly perpendicular to the flowlines.

Radar data were acquired using an airborne $60 \mathrm{MHz}$ INGV-IT digital radar, linked to a global positioning system (Tabacco and others, 1999). We used a $1 \mu$ s pulse length (about $160 \mathrm{~m}$ ice thickness), a $20 \mathrm{MHz}$ digital sampling frequency yielding an accuracy of $50 \mathrm{~ns}(\sim 8 \mathrm{~m}$ in ice). We acquired 10 traces $\mathrm{s}^{-1}$ (approximately 1 trace per $7 \mathrm{~m}$ at the main aircraft speed) with a time range of $64 \mu$ s. Ice thickness was calculated using a constant velocity of $168 \mathrm{~m} \mathrm{~s}^{-1}$ (Glen and Paren, 1975; Robin, 1975; Bogorodsky and others, 1985; Paterson, 1994). Cross-checking between the intersection of east-west and north-south profiles yields thickness differences of $<10 \mathrm{~m}$; the error in thickness determination along each transect is estimated at $<16 \mathrm{~m}$. Bed elevation was calculated by subtracting the ice thickness from the surface elevation obtained by the European Remote-sensing Satellite-1 radar altimeter data (Rémy and others, 1999).

\section{LAKE BOUNDARY}

It is well known that the reflection strengths from ice/water and ice/rock interfaces differ by $>10 \mathrm{~dB}$ due to the values of the real part of the dielectric constant of water and rock, and to the roughness of bedrock (Oswald and Robin, 1973; Siegert and others, 1996; Gorman and Siegert, 1999; Siegert, 2000). For this reason the variation of reflection strength along each transect was analyzed in order to obtain the accurate position of the grounding line. To evaluate the strength variation due only to the bottom interface, we need to remove from the measured bottom reflections all those contributions caused by overlying ice.

The reflected power $P_{\mathrm{R}}$ is calculated by:

$$
P_{\mathrm{R}}=G^{2} \frac{\lambda^{2}}{16 \pi^{2} r^{2}} P_{\mathrm{T}} Q \frac{L_{\mathrm{f}}}{L}
$$

where $G$ is the antenna gain, $\lambda$ is the wavelength, $r$ is the distance, $P_{\mathrm{T}}$ is the transmitted power, $Q$ is the refractive gain, $L_{\mathrm{f}}$ is the gain/loss due to the focusing/defocusing effect of surface shape and $L$ is the total power loss, due to volume inhomogeneity $\left(L_{\mathrm{v}}\right)$, ice-surface and ice-bottom scattering $\left(L_{\mathrm{si}}\right.$ and $\left.L_{\mathrm{sb}}\right)$, reflection at the ice/air and air/ice interfaces $\left(L_{\mathrm{r}}\right)$, polarization $\left(L_{\mathrm{p}}\right)$, medium absorption $\left(L_{\mathrm{a}}\right)$ and transmission at the bottom interface $\left(L_{\mathrm{t}}\right)$. 


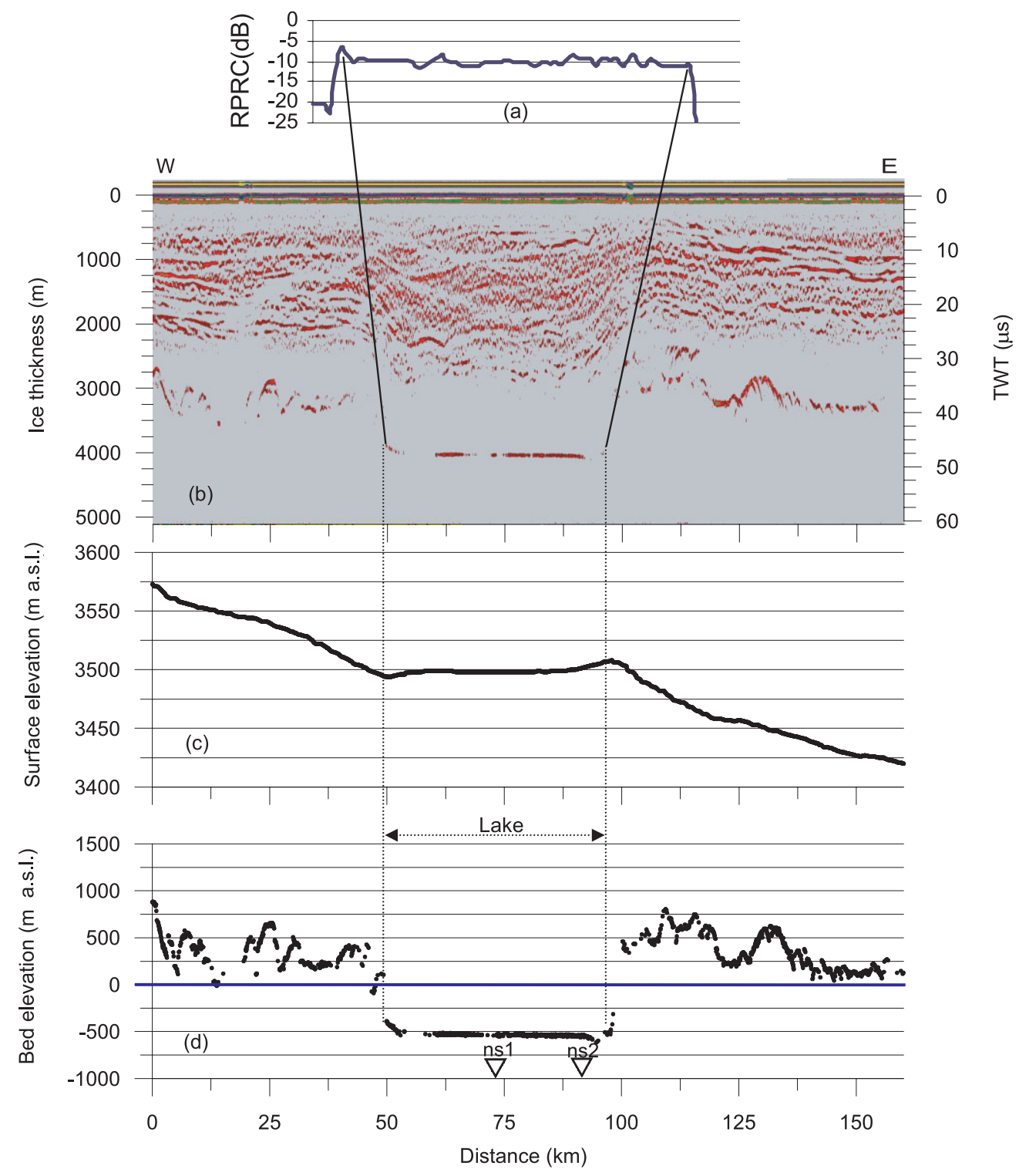

Fig. 3. Transect "ewe2". (a) RPRC; (b) radar sections with ice thickness and TWT; (c, d) surface and bed elevation, respectively $(m$ a.s.l.). $(\nabla)$ denotes cross-point between profiles.

Expressing Equation (1) in $\mathrm{dB}$ and considering geometrical attenuation $L_{\mathrm{g}}=20 \log (4 \pi r / G \lambda)$, we obtain:

$$
\begin{aligned}
{\left[P_{\mathrm{R}}\right]=} & {\left[P_{\mathrm{T}}\right]-\left[L_{\mathrm{g}}\right]+[Q]-\left[L_{\mathrm{f}}\right]-\left[L_{\mathrm{si}}\right] } \\
& -\left[L_{\mathrm{v}}\right]-\left[L_{\mathrm{p}}\right]-\left[L_{\mathrm{r}}\right]-\left[L_{\mathrm{a}}\right]-\left[L_{\mathrm{t}}\right]-\left[L_{\mathrm{sb}}\right] .
\end{aligned}
$$

The transmitted power $P_{\mathrm{T}}$ for the INGV-ITradar is $62.6 \mathrm{~dB}$. The refractive gain $Q$ and the focusing-defocusing effect $L_{\mathrm{f}}$ are 3-4 dB for nearly flat reflecting surfaces (Bogorodsky and others, 1985). The scattering loss from the ice/air interface, $L_{\mathrm{si}}$, ranges from near zero to several $\mathrm{dB}$ depending on surface roughness. In this work we assume a value of about $1-2 \mathrm{~dB}$ obtained after an averaging of raw data. Based on a preliminary elaboration of the raw data, we found that the values $L_{\mathrm{v}}$, $L_{\mathrm{p}}$ and $L_{\mathrm{r}}$ may be considered constant along each profile, and their total contribution is approximately $4 \mathrm{~dB}$.

With these assumptions:

$$
\left[P_{\mathrm{R}}\right]=\left(62.6-\left[L_{\mathrm{g}}\right]-\left[L_{\mathrm{a}}\right]-\left[L_{\mathrm{t}}\right]-\left[L_{\mathrm{sb}}\right]-2\right) \mathrm{dB},
$$

where $L_{\mathrm{t}}$ and $L_{\mathrm{sb}}$ are the two terms strictly related to the bottom interface; their sum might be considered as a relative power reflection coefficient (RPRC). Setting $[R P R C]=$ $\left[L_{\mathrm{t}}\right]+\left[L_{\mathrm{sb}}\right]$ we obtain:

$$
[\mathrm{RPRC}]=\left(62.6-\left[P_{\mathrm{R}}\right]-\left[L_{\mathrm{g}}\right]-\left[L_{\mathrm{a}}\right]-2\right) \mathrm{dB} .
$$

By measuring the amplitude of the echo signals $P_{\mathrm{R}}$, and the ice thickness, we are able to calculate $L_{\mathrm{g}}$ and $L_{\mathrm{a}}$, and finally RPRC. There are some problems with the calculation of $L_{\mathrm{a}}$. The absorption is given by $L_{\mathrm{a}}=k \sigma d$, where $k$ is a constant, $\sigma$ is the conductivity dependent on temperature and depth, and $d$ is the thickness; its estimation is influenced by errors due to uncertainty relating to the value of conductivity and to its variation with depth. We restricted the amplitude analysis to the lake and the surrounding shore; in this case, the depth difference between lake ceiling and bedrock is $<100 \mathrm{~m}$, so the errors due to an incorrect value of the absorption coefficient have little bearing upon the RPRC trend along the profiles at the lake/bedrock transition. The RPRC values and the bottom morphology were subsequently used to identify the grounding line. On the eastwest transects, bottom reflections with both very rough and flat morphology can be identified (Figs 2-5). On account of the reflection amplitude we are able to distinguish:

(1) a wide tract over the flat area, with a high and fairly constant (varying within $1 \mathrm{~dB}$ ) RPRC value, interpreted as an ice/water interface;

(2) a short tract, close to the western margins of the flat area, with a very high RPRC value (roughly $4 \mathrm{~dB}$ higher than 


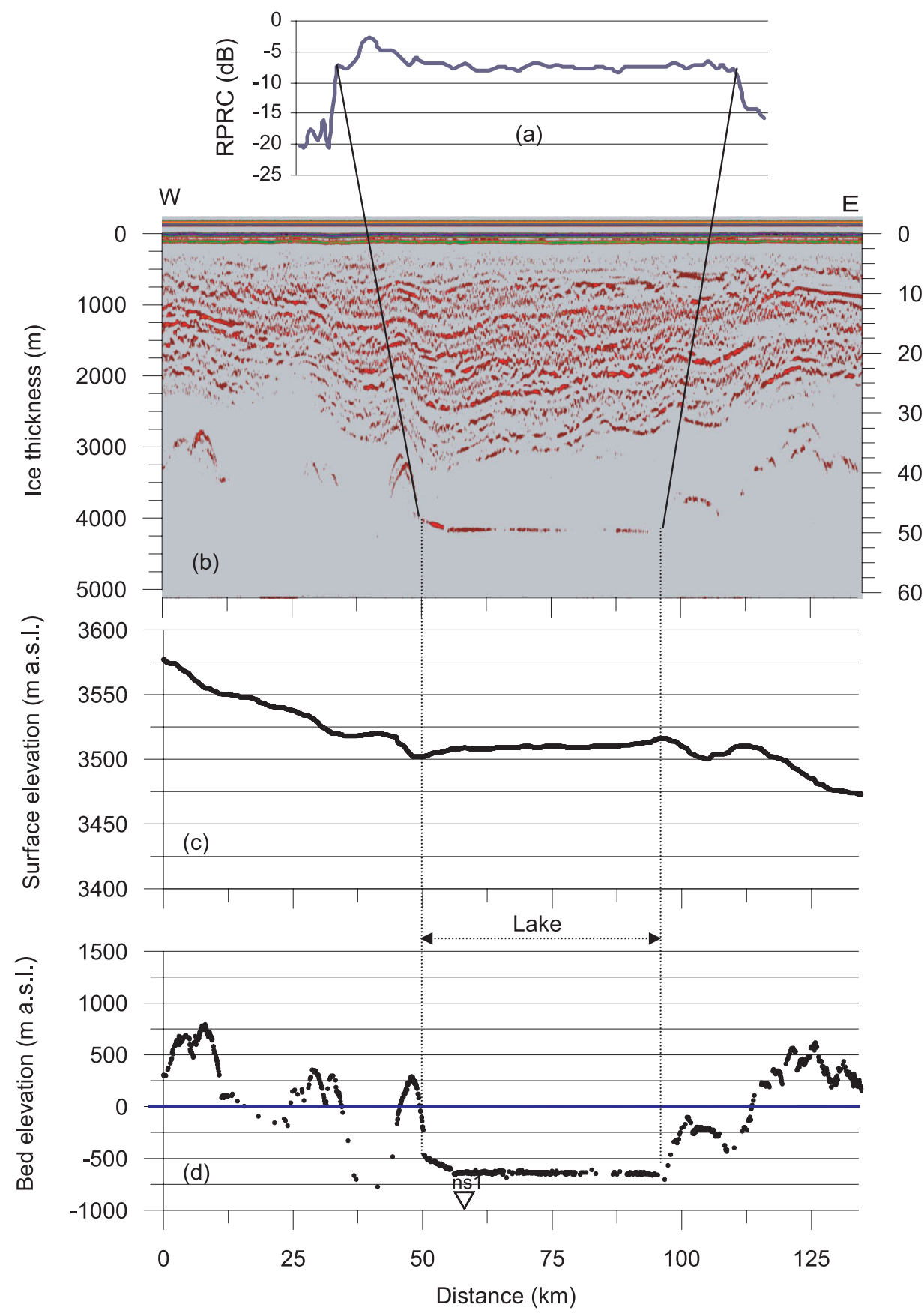

Fig. 4. Transect "ew3". ( a) RPRC; (b) radar sections with ice thickness and TWT; (c, d) surface and bed elevation, respectively ( $m$ a.s.l.). $(\nabla)$ denotes cross-point between profiles.

the previous one). This very high reflection strength is also interpreted as an ice/water interface and thus as a lake ceiling.

(3) surrounding tracts over a rough reflector with widely variable amplitude (varying up to $20 \mathrm{~dB}$ ) and low reflection strength (more than $10 \mathrm{~dB}$ lower than the flat area). These low and irregular values are typical features of an ice/rock interface.

Similar results were obtained for the north-south profiles.

\section{ICE THICKNESS}

Along the transect "nsl" (Fig. 6) ice thickness over the lake increases from $3799 \mathrm{~m}$ (south) to $4250 \mathrm{~m}$ (north). We can identify three sectors with a thickening rate that decreases from $\sim 5.9 \mathrm{~m} \mathrm{~km}^{-1}$ (south) to $\sim 2.5 \mathrm{~m} \mathrm{~km}^{-1}$ (central) to $\sim 1 \mathrm{~m}$ $\mathrm{km}^{-1}$ (north).
In each east-west transect (Figs 2-5) we distinguish three sectors:

(a) a western sector with a steep eastward ice thickening, located over the area with very high reflection strength. The thickening rate along the flight tracks is greater in the southern-central area $\left(20-43 \mathrm{~m} \mathrm{~km}^{-1}\right)$ than in the northern area $\left(8 \mathrm{~m} \mathrm{~km}^{-1}\right)$;

(b) a central sector with near-constant thickness;

(c) an eastern sector with sharp westward ice thickening.

Taking into account ice-thickness variation, the pressuredependent freezing temperature at the lake ceiling and the horizontal temperature gradient were calculated for each sector, according to the equation $T(p)=T(0)-0.00753 p$, where $T$ is the freezing temperature at pressure $p$ (expressed in bar) and $T(0)$ is assumed to be $0^{\circ} \mathrm{C}$ (Fujino and others, 1974; Souchez and others, 2000; Wüest and Carmack, 2000). The tem- 


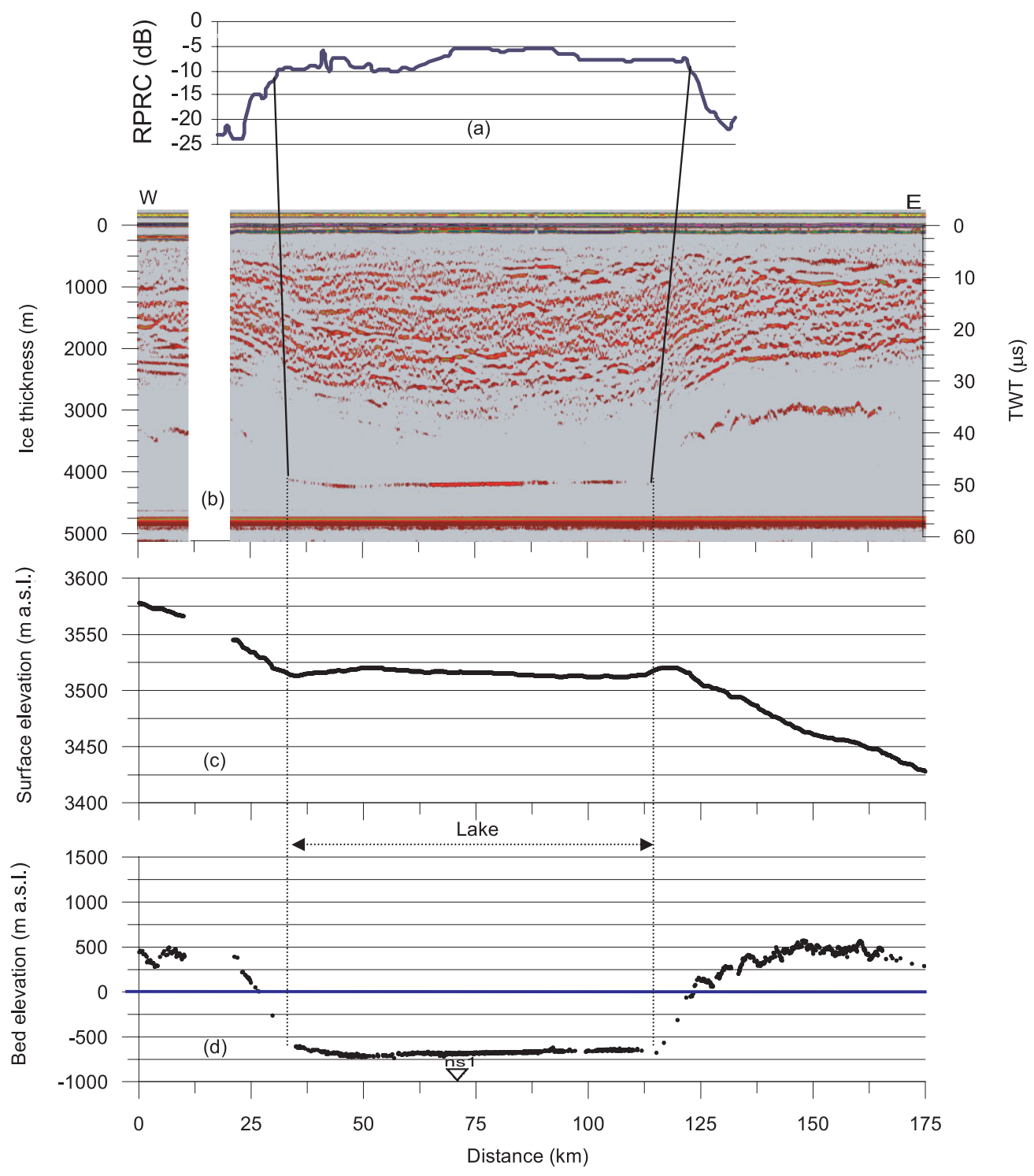

Fig. 5. Transect "ew4". (a) RPRC; (b) radar sections with ice thickness and TWT; $(c, d)$ surface and bed elevation, respectively $(m$ a.s.l.). $(\nabla)$ denotes cross-point between profiles.

perature gradients of the western and eastern sectors are greater than those in the north-south sectors (Table 1).

\section{SURFAGE AND BED TOPOGRAPHY}

The subglacial topography surrounding the lake is highly complex and irregular; bed elevation ranges between -750 and $+1000 \mathrm{~m}$ a.s.l. The western and eastern lake shores along the south-central area have a gradient of $>100 \mathrm{~m} \mathrm{~km}^{-1}$, and at the northern end the bedrock gradient is lower at $\sim 80 \mathrm{~m} \mathrm{~km}^{-1}$ (Fig. 7). LakeVostok occupies a depression elongated parallel to the boundary between the Vostok Subglacial Highlands and the western Aurora Basin. This depression is at least 260 by $80 \mathrm{~km}$, with the longer axis north-northwestsouth-southeast oriented. A rift, with a possible link to a rifting system entering inland from the Amery Basin, has been proposed by Leitchenkov and others (1998). We note that the lake-flanking bed morphology does not evidence any smoothing effects of substantial surface erosion or sedimentation processes. Hence, these indications strongly suggest that the depression developed over a relatively short geological time, most probably during the Cenozoic period (Leitchenkov and others, 1998; Dalziel, 1998).
Over the lake, the ice surface elevation (Rémy and others, 1999) increases from $3476 \mathrm{~m}$ (south) to $3525 \mathrm{~m}$ (north), with an average northward gradient of $0.2 \mathrm{~m} \mathrm{~km}^{-1}$, while the lake-ceiling elevation decreases from $-315 \mathrm{~m}$ (south) to $-750 \mathrm{~m}$ (north), with an average northward gradient of $-1.7 \mathrm{~m} \mathrm{~km}^{-1}$. The ratio between lake-ceiling and surface slope gradients is -8.5 . Neither surface nor ceiling slope from south to north is constant, and we may distinguish three sectors (Fig. 6): sector 1, between 0 and $25 \mathrm{~km}$ (surface gradient $0.5 \mathrm{~m} \mathrm{~km}^{-1}$, ceiling gradient -5.9 , ceiling/surface gradient ratio -11.8 ); sector 2, between 25 and $70 \mathrm{~km}$ (surface $0.3 \mathrm{~m} \mathrm{~km}^{-1}$, ceiling $-2.6 \mathrm{~m} \mathrm{~km}^{-1}$, ratio -8.7 ); and sector 3 , between 70 and $260 \mathrm{~km}$ (surface $0.1 \mathrm{~m} \mathrm{~km}^{-1}$, ceiling $-0.9 \mathrm{~m}$ $\mathrm{km}^{-1}$, ratio -9.0 ). The values of the ratio between lake-ceiling and ice-surface gradients are consistent with the ice and lake model in hydrostatic equilibrium, where the gradients of ice/ water interface must be approximately 10 times, and in the opposite direction to, the ice-surface gradient (Oswald and Robin, 1973). The surface and bed elevation over the central part of the lake are fairly constant on all the east-west transects.

Along the western side, over a narrow strip $(<5 \mathrm{~km}$ long) the surface topography indicates a trough roughly $8 \mathrm{~m}$ deep, while the lake ceiling dips with a gradient ranging from $8 \mathrm{~m} \mathrm{~km}^{-1}$ (transect "ew4") to $40 \mathrm{~m} \mathrm{~km}^{-1}$ (transect "ew2"). 


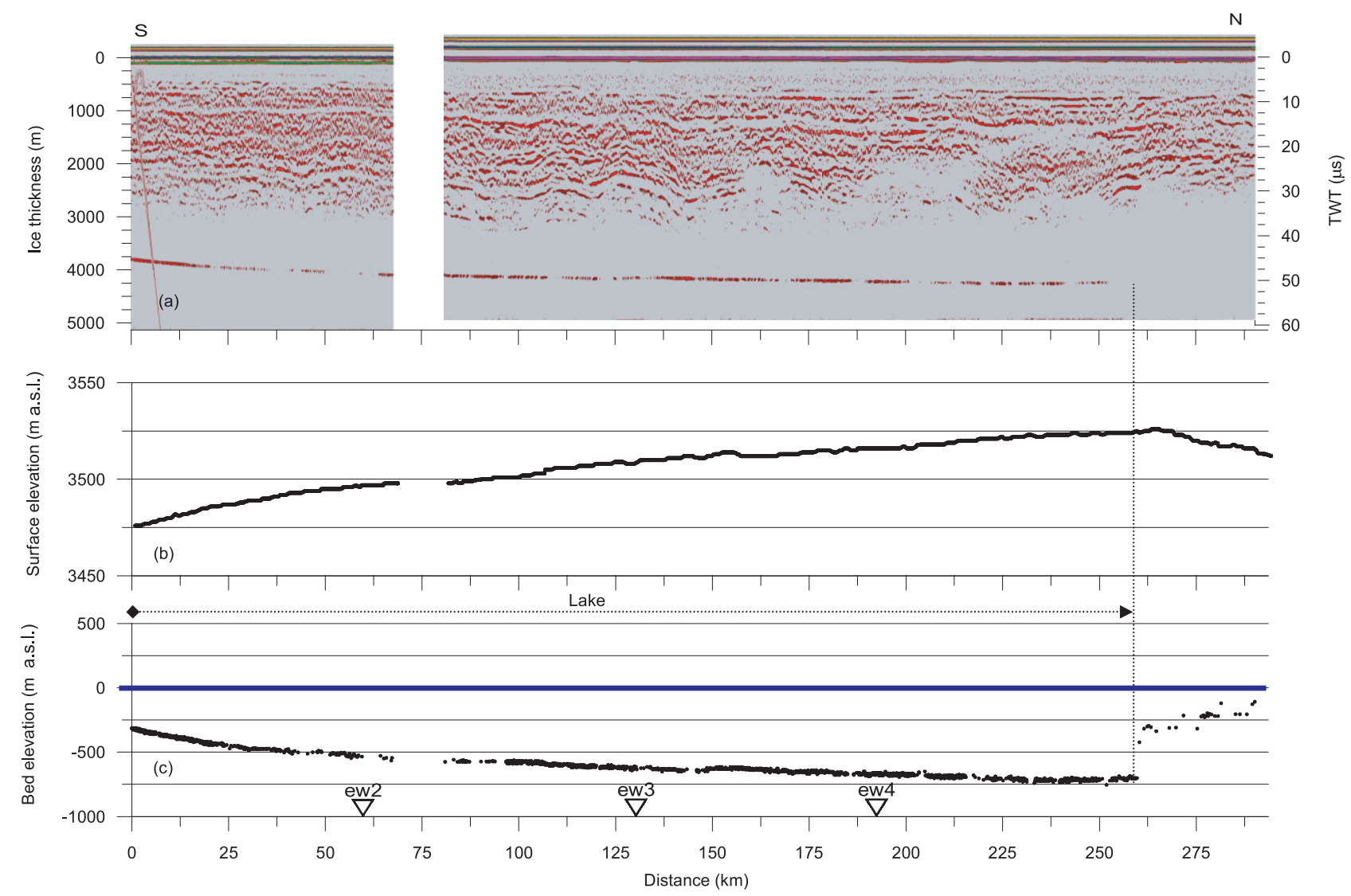

Fig. 6. Transect "nsl". (a) Radar sections with ice thickness and TWT; (b, c) surface and bed elevation, respectively ( $m$ a.s.l.).

$(\nabla)$ denotes cross-point between profiles.

Along the eastern side, confined to the central southern part of the lake, surface topography indicates a peak about $7 \mathrm{~m}$ high, while the lake ceiling dips with a rate of about $15 \mathrm{~m} \mathrm{~km}^{-1}$. We may assume that these features are due to downslope and upslope motions produced by a mechanism driven by a change in ice dynamics from grounded, floating and regrounded ice (Kapitsa and others, 1996; Siegert and Ridley, 1998).

\section{DISGUSSION AND GONGLUSION}

The amplitude analysis allowed for a definition of the nature of bottom interfaces and for unambiguous positioning of the grounding line indicated by sharp amplitude changes. Our radar data confirm the geometry of Lake Vostok derived from previous analysis, but with some slight differences, the main one being the extent of the lake. We measured a length of up

Table 1. Features of the lake derived from radar transects. Thickening rate and horizontal temperature gradient are calculated from west to east and from south to north

\begin{tabular}{|c|c|c|c|c|c|c|c|c|c|}
\hline \multirow[t]{2}{*}{ Transect } & Lake length & \multicolumn{2}{|c|}{ Lake boundary coordinates } & \multirow[t]{2}{*}{ Lake sector } & \multirow{2}{*}{$\begin{array}{c}\text { Length } \\
\mathrm{km}\end{array}$} & \multirow{2}{*}{$\begin{array}{c}\text { Minimum } \\
\text { thickness } \\
\text { m }\end{array}$} & \multirow{2}{*}{$\begin{array}{l}\text { Maximum } \\
\text { thickness } \\
\mathrm{m}\end{array}$} & \multirow{2}{*}{$\begin{array}{c}\text { Thickening } \\
\text { rate } \\
\mathrm{m} \mathrm{km}^{-1}\end{array}$} & \multirow{2}{*}{$\begin{array}{l}\text { Horizontal temperature } \\
\text { gradient } \\
\mathrm{K} \mathrm{m}^{-1}\end{array}$} \\
\hline & $\mathrm{km}$ & & & & & & & & \\
\hline ewl & 16.8 & $\begin{array}{l}78.4918^{\circ} \mathrm{S} \\
78.4433^{\circ} \mathrm{S}\end{array}$ & $\begin{array}{l}106.3908^{\circ} \mathrm{E} \\
107.0862^{\circ} \mathrm{E}\end{array}$ & $\begin{array}{l}\text { Western } \\
\text { Central } \\
\text { Eastern }\end{array}$ & $\begin{array}{r}3.2 \\
11.0 \\
2.6\end{array}$ & $\begin{array}{l}3725 \\
3791 \\
3781\end{array}$ & $\begin{array}{r}3791 \\
3781 \\
3845\end{array}$ & $\begin{array}{r}20.5 \\
>-0.1 \\
24.7\end{array}$ & $\begin{array}{c}1.4 \times 10^{-5} \\
-6.1 \times 10^{-7} \\
1.6 \times 10^{-5}\end{array}$ \\
\hline ew2 & 46.1 & $\begin{array}{l}77.9219^{\circ} \mathrm{S} \\
77.9033^{\circ} \mathrm{S}\end{array}$ & $\begin{array}{l}104.8826^{\circ} \mathrm{E} \\
106.9810^{\circ} \mathrm{E}\end{array}$ & $\begin{array}{l}\text { Western } \\
\text { Central } \\
\text { Eastern }\end{array}$ & $\begin{array}{r}2.9 \\
39.0 \\
4.2\end{array}$ & $\begin{array}{r}3894 \\
4021 \\
4045\end{array}$ & $\begin{array}{r}4021 \\
4045 \\
4132\end{array}$ & $\begin{array}{r}43.5 \\
0.6 \\
20.8\end{array}$ & $\begin{array}{l}2.9 \times 10^{-5} \\
4.1 \times 10^{-7} \\
1.4 \times 10^{-5}\end{array}$ \\
\hline ew3 & 46.6 & $\begin{array}{l}77.4155^{\circ} \mathrm{S} \\
77.3021^{\circ} \mathrm{S}\end{array}$ & $\begin{array}{l}104.4775^{\circ} \mathrm{E} \\
106.3284^{\circ} \mathrm{E}\end{array}$ & $\begin{array}{l}\text { Western } \\
\text { Central } \\
\text { Eastern }\end{array}$ & $\begin{array}{r}5.9 \\
36.9 \\
3.8\end{array}$ & $\begin{array}{r}3994 \\
4141 \\
4160\end{array}$ & $\begin{array}{l}4141 \\
4156 \\
4199\end{array}$ & $\begin{array}{r}24.9 \\
<0.1 \\
10.1\end{array}$ & $\begin{array}{l}1.7 \times 10^{-5} \\
2.7 \times 10^{-7} \\
6.9 \times 10^{-6}\end{array}$ \\
\hline nsl & 261.7 & $\begin{array}{l}78.4732^{\circ} \mathrm{S} \\
76.2724^{\circ} \mathrm{S}\end{array}$ & $\begin{array}{l}106.8184^{\circ} \mathrm{E} \\
103.1160^{\circ} \mathrm{E}\end{array}$ & $\begin{array}{l}\text { Southern } \\
\text { Central } \\
\text { Northern }\end{array}$ & $\begin{array}{r}25.0 \\
45.0 \\
191.7\end{array}$ & $\begin{array}{l}3799 \\
3946 \\
4058\end{array}$ & $\begin{array}{l}3946 \\
4058 \\
4250\end{array}$ & $\begin{array}{l}5.9 \\
2.5 \\
1.0\end{array}$ & $\begin{array}{l}3.9 \times 10^{-6} \\
1.7 \times 10^{-6} \\
6.7 \times 10^{-7}\end{array}$ \\
\hline
\end{tabular}




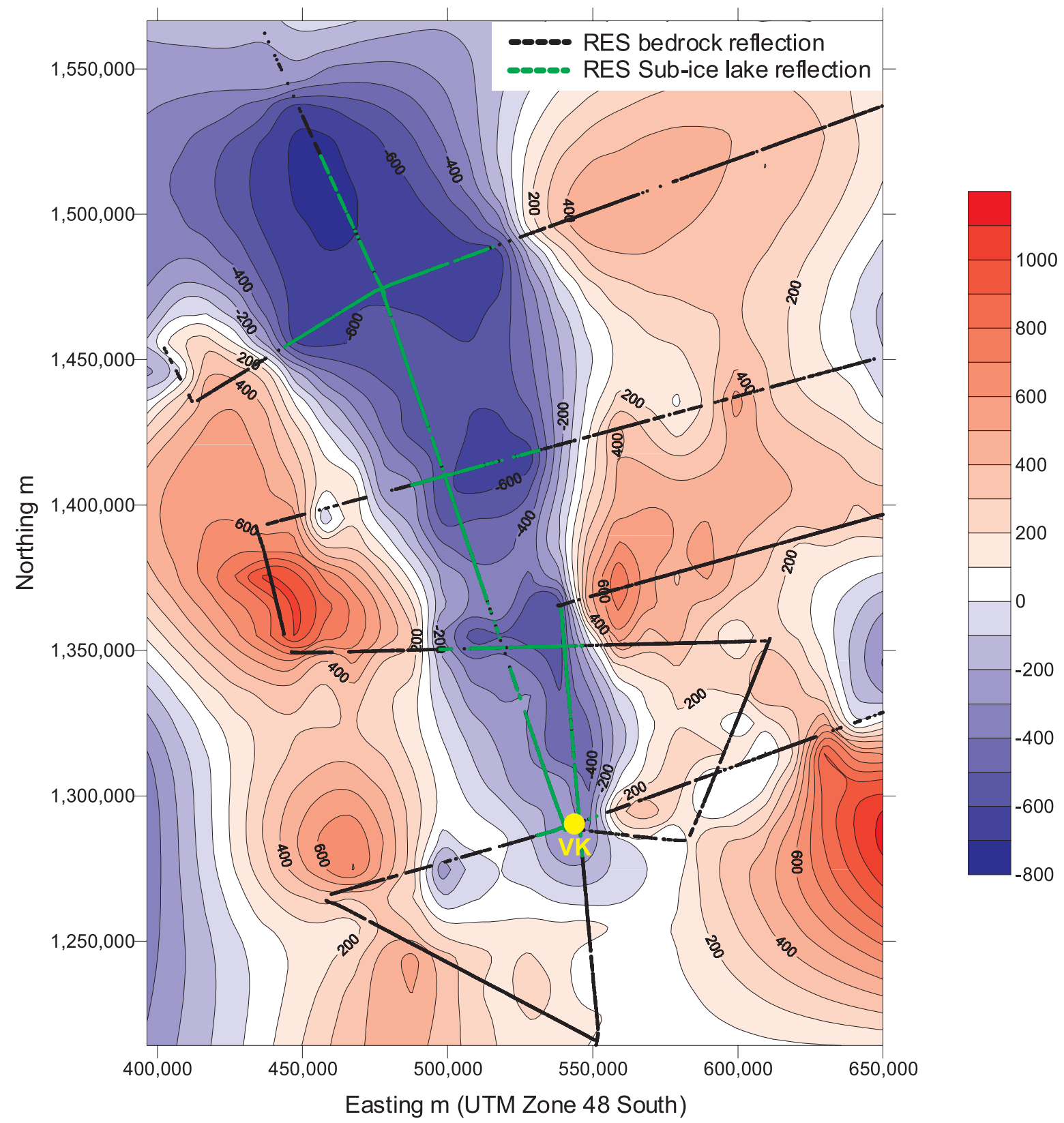

Fig. 7. Bed elevation ( $m$ a.s.l.) of the Vostok area with tracks of radar lines. Contour lines $100 \mathrm{~m}$.VK, Vostok station.

to $260 \mathrm{~km}$ and a maximum width of $81 \mathrm{~km}$. A map of surface slopes superimposed on the radar tracks showing lake reflections is given in Figure 8. Lake boundaries derived from radar measurements are highly appropriate for areas with a slope gradient of $<0.02 \%$. It should be noted that both the surface "trough", running along the western lake shores, and the "peak" along the eastern shores (slope gradient ranges: $0.02-0.1 \%$ and $0.1-0.2 \%$ ) are to be included in the lake body. The lake area, calculated on the basis of surface area with slope $<0.02 \%$, is about $14000 \mathrm{~km}^{2}$; this value is affected by some uncertainties due to the location of the northern boundaries, and represents the minimum area.

Ice-surface and lake-ceiling ratios from south to north confirm the ice--water model in hydrostatic equilibrium.

Finally, we should point out that, along the western and eastern edges, lake-ceiling temperatures are higher and lower, respectively, than those over the central body of the lake. The east-west horizontal gradients on the pressuredependent freezing temperature should be taken into account, in addition to the north-south gradient (e.g. Wüest and Carmack, 2000), when modelling water circulation.

\section{ACKNOWLEDGEMENTS}

Research was carried out in the framework of the Project on Glaciology and Paleoclimatology of the Italian Programma Nazionale di Ricerche in Antartide. The work was made possible by logistical support from Ente per le Nuove Tecnologie, l'Energia e l'Ambiente; in particular we thank M. Zucchelli for his decisive contribution. We thank G. Orombelli and M. Frezzotti for their suggestions and R. A. Bindschadler (Scientific Editor), M.J. Siegert and the anonymous reviewer for their critical and useful observations.

\section{REFERENGES}

Bogorodsky, V.V., C. R. Bentley and P. E. Gudmandsen. 1985. Radioglaciology. Dordrecht, etc., D. Reidel Publishing Co.

Dalziel, I.W. D. 1998. Tectonic setting of Lake Vostok. In Bell, R. E. and D. M. Karl, eds. Lake Vostok final workshop report, 7-8 November 1998, Washington D.C. New York, Columbia University Press, 17-19.

Fujino, K., E. L. Lewis and R. G. Perkin. 1974. The freezing point of seawater at pressures up to 100 bars. F. Geophys. Res., 79(12), 1792-1797.

Glen, J.W. and J. G. Paren. 1975. The electrical properties of snow and ice. F. Glaciol., 15(73), 15-38.

Gorman, M. R. and M. J. Siegert. 1999. Penetration of Antarctic subglacial 


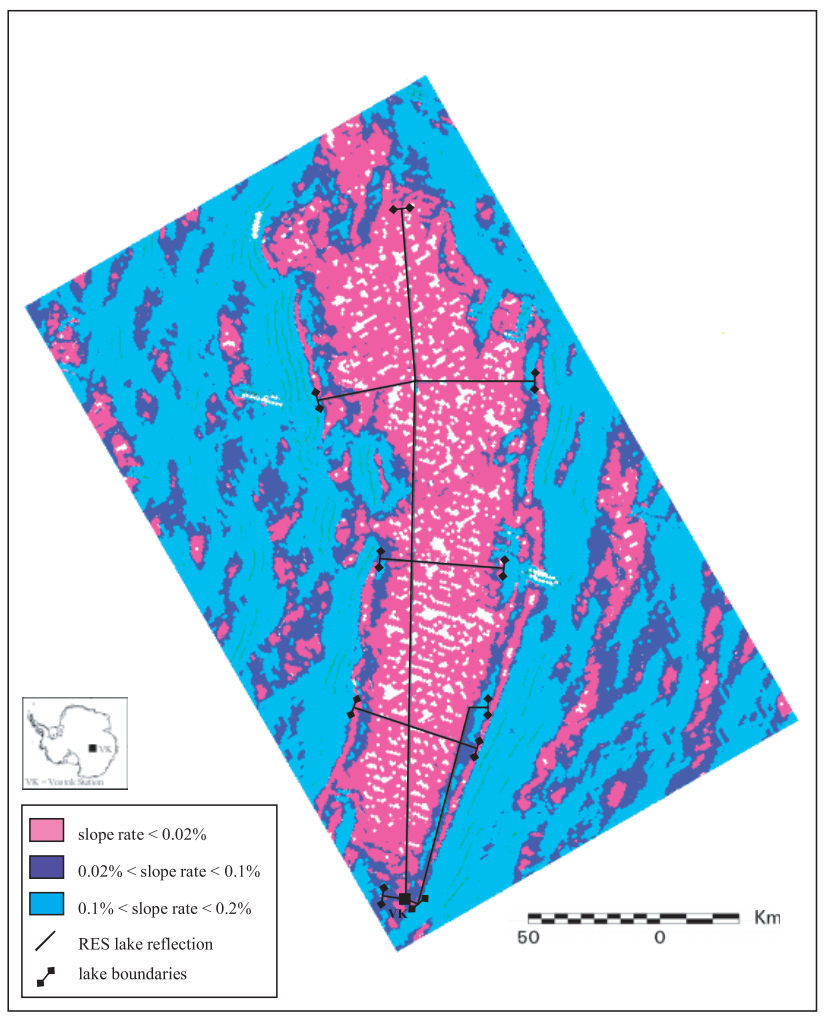

Fig. 8. Map of surface slope gradients superimposed on the tracks of radar reflections from the lake.

lakes by VHF electromagnetic pulses: information on the depth and electrical conductivity of basal water bodies. F. Geophys. Res., 104(B12), 29,311-29,320.

Jouzel, J. and 9 others. 1999. More than $200 \mathrm{~m}$ of lake ice above subglacial Lake Vostok, Antarctica. Science, 286(5447), 2138-2141.

Kapitsa, A. P., J. K. Ridley, G. de Q. Robin, M. J. Siegert and I. Zotikov.
1996. A large deep freshwater lake beneath the ice of central East Antarctica. Nature, 381 (6584), 684-686.

Kwok, R., M. J. Siegert and F. D. Carsey. 2000. Ice motion over Lake Vostok, Antarctica: constraints on inferences regarding the accreted ice. F. Glaciol., 46(155), 689-694.

Leitchenkov, G. L., S. R. Verkulich and V. N. Masolov. 1998. Tectonic setting of Lake Vostok and possible information contained in its bottom sediments. In Lake Vostok study: scientific objectives and technological requirements. International workshop. Abstracts. Sankt Peterburg, Arctic and Antarctic Research Institute, 62-65.

Oswald, G. K. A. and G. de Q. Robin. 1973. Lakes beneath the Antarctic ice sheet. Nature, 245(5423), 251-254.

Paterson, W. S. B. 1994. The physics of glaciers. Third edition. Oxford, etc., Pergamon Press.

Rémy, F., P. Shaeffer and B. Legrésy. 1999. Ice flow physical processes derived from ERS-1 high-resolution map of Antarctica and Greenland ice sheet. Geophys. 7. Int., 139(3), 645-656.

Ridley, J. K., W. Cudlip and S.W. Laxon. 1993. Identification of subglacial lakes using ERS-1 radar altimeter. F. Glaciol., 39(133), 625-634.

Robin, G. de Q. 1975. Velocity of radio waves in ice by means of a bore-hole interferometric technique. F. Glaciol., 15(73), 151-159.

Siegert, M. J. 2000. Antarctic subglacial lakes. Earth Sci. Rev., 50(1-2), 29-50.

Siegert, M. J. andJ. K. Ridley. 1998. An analysis of the ice-sheet surface and subsurface topography above the Vostok Station subglacial lake, central East Antarctica. F. Geophys. Res., 103(B5), 10,195-10,207.

Siegert, M. J., J. A. Dowdeswell, M. R. Gorman and N. F. McIntyre. 1996. An inventory of Antarctic sub-glacial lakes. Antarct. Sci., 8 (3), 281-286.

Siegert, M. J., R. Kwok, C. Mayer and B. Hubbard. 2000. Water exchange between the subglacial Lake Vostok and the overlying ice sheet. Nature, 403(6770), 643-646.

Souchez, R., J. R. Petit, J. L. Tison, J. Jouzel and V. Verbeke. 2000. Ice formation in subglacial Lake Vostok, central Antarctica. Earth Planet. Sci. Lett., 181 (4), 529-538.

Tabacco, I. E., G. Bianchi, M. Chiappini, A. Passerini, A. Zirizzotti and E. Zuccheretti. 1999. Latest improvements for the echo sounding system of the Italian radar glaciological group and measurements in Antarctica. Ann. Geofis., 42 (2), 271-276.

Wüest, A. and E. Carmack. 2000. A priori estimates of mixing and circulation in the hard-to-reach water body of Lake Vostok. Ocean Modelling, 2, 29-43.

MS received 15 March 2001 and accepted in revised form 8 December 2001 